\title{
Analisis pembelajaran aspek kognitif materi pendidikan jasmani olahraga dan kesehatan SMA/SMK
}

\author{
Ahmad Rithaudin*, Indah Prasetyowati Tri Purnama Sari \\ Fakultas IImu Keolahragaan Universitas Negeri Yogyakarta \\ Jalan Colombo No. 1 Karangmalang, Yogyakarta 55281, Indonesia \\ Corresponding Author. Email: a_rithaudin@uny.ac.id
}

\begin{abstract}
Abstrak
Penelitian ini dilatarbelakangi oleh permasalahan ditemuinya kesulitan guru dalam penyusunan Rencana Pelaksanaan Pembelajaran (RPP) dengan isi materi yang mencakup tiga tujuan utama pembelajaran yaitu kognitif, afektif dan psikomotor. Penelitian ini bertujuan untuk menganalisis pembelajaran pada aspek kognitif yang terdapat dalam RPP mata pelajaran penjasorkes di SMA/SMK di Daerah Istimewa Yogyakarta (DIY). Desain dalam penelitian ini adalah deskriptif kuantitatif, dengan metode analisis dokumen. Subyek dalam sekolah mitra UNY pada tahun 2015 yang berjumlah 21 sekolah. Adapun data yang didapatkan adalah 19 RPP dari 19 sekolah. Instrumen dalam penelitian ini adalah lembar analisis dokumen. Hasil yang didapatkan dalam penelitiann ini dapat disimpulkan bahwa secara umum terdapat materi pembelajaran pada aspek kognitif dalam RPP pembelajaran penjasorkes SMA Mitra UNY di DIY. Kemudian jika analisis dilakukan terhadap indikator yang dikembangkan, indikator yang berkaitan dengan pengembangan kompetensi kognitif siswa hanya muncul di dalam RPP yang kembangkan dengan kurikulum tahun 2013. Untuk uraian materi yang dikembangkan, hampir semua RPP yang kembangkan secara minimal telah mencantumkan materi yang berkaitan dengan pengembangan kompetensi kognitif siswa. Kecenderungan materi lebih lengkap apabila RPP tersebut disusun berdasar kurikulum tahun 2013.
\end{abstract}

Kata Kunci: analisis, pembelajaran, kognitif, SMA/SMK

\section{Learning analysis of cognitive aspects of sports and health education materials in high school and vocational school}

\begin{abstract}
This research is motivated by problems encountered by the teacher's difficulties in the preparation of the lesson plan (RPP) with the contents of the material which includes three main objectives of learning, namely cognitive, affective and psychomotor. This study aims to analyze learning on cognitive aspects contained in the RPP of physical education courses in high schools / vocational schools in the Special Region of Yogyakarta (DIY). The design in this study is descriptive quantitative, with document analysis methods. The subjects in the Universitas Negeri Yogyakarta (UNY) partner schools in 2015 were 21 schools. The data obtained are 19 lesson plans from 19 schools. The instrument in this study is a document analysis sheet. The results obtained in this research can be concluded that in general there are learning material on cognitive aspects in the lesson plan for physical education in high school UNY partners in Special Region of Yogyakarta (DIY). Then if the analysis is carried out on the indicators developed, indicators relating to the development of student cognitive competencies only appear in the RPP developed with the 2013 curriculum. For the description of the material developed, almost all RPPs that have developed have included material related to competency development. Cognitive students. Material trends are more complete if the RPP is prepared based on the 2013 curriculum.
\end{abstract}

Keywords: analysis, learning, cognitive, high school/vocational school

\section{PENDAHULUAN}

Hakikat pembelajaran pendidikan jasmani bisa dijelaskan berdasar dua pendapat yaitu hakikat pembelajaran dan pendidikan jasmani. Hakikat pembelajaran lebih dari sekedar pengajaran pengetahuan dari seorang guru kepada siswanya, lebih dari itu dalam proses pembelajaran harapannya seorang pendidik bisa mengoptimalkan seluruh potensi yang ada 
pada diri siswa. Hakikat Pendidikan jasmani memiliki dua asumsi yaitu pendidikan melalui jasmani dan pendidikan untuk jasmani (Bucher \& Wuest, 1983, p. 25). Berdasar pada asumsi pertama dapat dijelaskan bahwa pendidikan jasmani merupakan sebuah proses pendidikan yang menggunakan aktivitas jasmani yang sengaja dipilih untuk mencapai tujuan pendidikan. Sedangkan asumsi yang kedua pendidikan jasmani diasumsikan sebagai sebuah media yang dapat dimanfaatkan untuk kebutuhan peningkatan kemampuan jasmani.

Tujuan yang ada di dalam pendidikan jasmani harapannya mengacu pada fungsi dan tujuan pendidikan nasional. Adapun fungsi dan tujuan pendidikan nasional adalah mengembangkan kemampuan dan membentuk watak serta peradaban bangsa yang bermartabat dalam rangka mencerdaskan kehidupan bangsa, bertujuan untuk berkembangnya potensi peserta didik agar menjadi manusia yang beriman dan bertakwa kepada Tuhan Yang Maha Esa, berakhlak mulia, sehat, berilmu, cakap, kreatif, mandiri, dan menjadi warga negara yang demokratis serta bertanggung jawab (UU SISDIKNAS, 2003, p. 4). Berdasar pada fungsi dan tujuan pendidikan nasional tersebut di atas, dapat diasumsikan bahwa tujuan pendidikan jasmani harapannya bisa senada dengan fungsi dan tujuan pendidikan nasional tersebut, karena apabila diidentifikasi tujuan yang ada di dalam undangundang sistem pendidikan nasional dapat dirangkum kedalam tiga aspek yaitu kognitif, afektif dan psikomotor. Selain itu berdasar undang-undang tersebut salah satu tujuan pendidikan jasmani harapannya juga mencakup aspek fisik atau jasmani (kebugaran jasmani).

Pembelajaran pendidikan jasmani di sekolah biasa di sebut dengan pembelajaran pendidikan jasmani olahraga dan kesehatan (penjasorkes) atau PJOK. Pembelajaran penjas di Indonesia saat ini mengacu pada kurikulum berbasis kompetensi, artinya di dalam proses pembelajaran terdapat kompetensi-kompetensi yang harus dikuasai oleh siswa sebagai tujuan pembelajaran. Berdasar kurikulum tahun 2013 terdapat empat kompetensi inti yang harus dikuasai oleh siswa yaitu kompetensi inti pertama (KI-1) tentang kompetensi sikap spiritual, $\mathrm{KI}-2$ tentang kompetensi sikap sosial, kedua $\mathrm{KI}$ tersebut bisa digolongkan ke dalam aspek afektif. Sedangkan KI-3 memuat tentang aspek kognitif dan KI-4 memuat tentang aspek psikomotor. Selain itu, beberapa sekolah juga masih menerapkan model kurikulum tahun 2006 atau yang biasa disebut KTSP.

Kognitif sebagai salah satu tujuan utama pembelajaran penjas, dan apabila dianalisis lebih lanjut, dari keempat tahapan dalam pembelajaran selalu melalui tahapan kognitif terlebih dahulu. Sebagai contoh, dalam melakukan sebuah gerak dasar permainan, pertama kali yang akan dilakukan oleh siswa adalah bagaimana memahami gerakan yang akan dilakukan. Selanjutnya mencoba untuk berpikir bagaimana cara melakukannya. Demikian juga halnya dengan aspek afektif, siswa akan mencoba memahami batasan-batasan dari sebuah pembelajaran terlebih dahulu sebelum mereka mengimplementasikannya dalam pembelajara tersebut, ataupun secara umum diimplementasikan dalam kehidupan sehari-hari.

Ranah Kognitif berisi tentang perilaku-perilaku yang menekankan aspek intelektual, seperti pengetahuan, pengertian, dan keterampilan berpikir (Siyamta, 2013, p. 8). Pada pembelajaran pendidikan jasmani, terutama dengan kurikulum tahun 2013 kompetensi kognitif merupakan salah satu kompetensi yang harus dikuasai oleh siswa. Akan tetapi di dalam kurikulum tahun 2006 hal ini tidak terlalu mendapat perhatian, meskipun secara umum tujuan pembelajaran mesti mencakup tiga ranah utama pembelajaran yaitu kognitif, afektif dan psikomotor. Berikut ini akan disajikan contoh kompetensi kognitif yang harus dikuasai oleh siswa SMA yaitu, menganalisis variasi dan kombinasi keterampilan gerak salah satu permainan bola besar untuk menghasilkan koordinasi gerak yang baik (Kemendikbud, 2013).

Berdasar pada narasi kompetensi dasar yang tersaji dalam permendikbud tersebut, dapat dianalisis bahwa kata kunci komponen kognitif yang ingin dikembangkan pada diri siswa adalah kemampuan untuk menganalisis permainan yang dilakukan. Namun, secara pasti apakah kompetensi dasar tersebut dikembangkan oleh guru menjadi indikator dan tujuan pembelajaran serta materi yang sesuai dengan kompetensi dasar yang diarahkan sementara belum bisa diketahui. Sehingga dalam penelitian ini ingin mencoba menganalisis aktivitasaktivitas yang berkaitan dengan pengembangan aspek kognitif siswa dalam pembelajaran penjasorkes di SMA/SMK se-DIY. 


\section{Jurnal Pendidikan Jasmani Indonesia, 15 (1), 2019 - 35}

Ahmad Rithaudin, Indah Prasetyowati Tri Purnama Sari

\section{Hakikat pembelajaran pendidikan jasmani}

Hakikat pembelajaran pendidikan jasmani bisa dijelaskan berdasar dua pendapat yaitu hakikat pembelajaran dan pendidikan jasmani. Hakikat pembelajaran lebih dari sekedar pengajaran pengetahuan dari seorang guru kepada siswanya, lebih dari itu dalam proses pembelajaran harapannya seorang pendidik bisa mengoptimalkan seluruh potensi yang ada pada diri siswa. Pembelajaran harapannya bisa membuka pintu gerbang kemungkinan untuk menjadi manusia dewasa dan mandiri serta pembelajaran memungkinkan seorang anak manusia berubah, dari tidak mampu menjadi mampu, (Harefa, 2006:36).

Apabila definisi tersebut dikaitkan dengan pendidikan jasmani, maka dapat diartikan bahwa pembelajaran pendidikan jasmani adalah sebuah usaha untuk mengoptimalkan seluruh potensi siswa serta membuka kemungkinan untuk menjadikan anak lebih dewasa melalui aktivitas jasmani yang digunakan sebagai media utamanya. Berdasar definisi tersebut maka dapat disimpulkan bahwa pembelajaran pendidikan jasmani mencakup tiga hal yaitu pendidikan jasmani merupakan bagian dari proses pendidikan secara menyeluruh, mempunyai tujuan yang spesifik dan menggunakan media yang spesifik juga untuk mencapai tujuannya yaitu menggunakan aktivitas jasmani atau gerak manusia.

Media utama dalam pembelajaran pendidikan jasmani (di sekolah-penjasorkes) adalah gerak manusia. Gerak manusia adalah perubahan posisi dalam ruang atau terhadap bagian tubuh lainnya (Abdullah \& Manadji, 1994, p.6). Kemampuan seseorang untuk melakukan gerakan bisa dipengaruhi oleh beberapa faktor, adapun faktor-faktor tersebut adalah karakteristik jasmani, kemampuan gerak, rasa aman, kemampuan perseptual, kecerdasan serta emosi (Abdullah \& Manadji, 1994, p.9). Keenam faktor tersebut perlu menjadi perhatian bagi seorang pendidik terutama dalam pendidikan jasmani agar tujuan pembelajaran yang diharapkan bisa lebih terarah dan tercapai.

\section{Tingkatan proses kognitif}

Salah satu tujuan utama dalam pembelajaran pendidikan jasmani olahraga dan kesehatan adalah aspek kognitif. Aspek kognitif menurut Bloom merupakan salah satu tujuan utama yang hendak dicapai dalam proses pembelajaran. Aspek kognitif secara teoritis digambarkan memiliki tingkat kompleksitas yang bervariasi, salah satu dari hirarki tersebut dalah seperti yang disampaikan oleh Bloom. Dalam gambar di bawah ini akan disajikan hierarki ranah kognitif menurut Bloom (Siyamta, 2013, p.9).

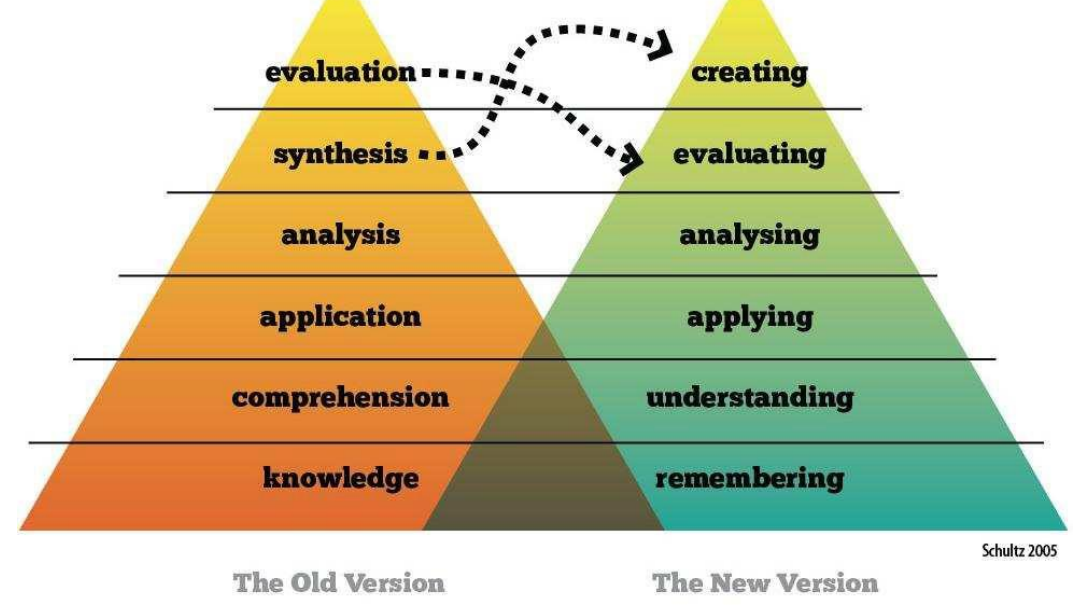

Gambar 1. Hierarki ranah kognitif menurut Bloom (Siyamta, 2013, p.9).

Berdasar Gambar 1, terdapat dua versi hirarki aspek kognitif (versi lama dan versi baru). Berikut ini akan disampaikan penjelasan terhadap deskripsi dari dua versi tersebut. Tiga level pertama (terbawah) merupakan Lower Order Thinking Skills, sedangkan tiga level berikutnya Higher Order Thinking Skill (Utari, 2013, p.3). Higher Order Thinking Skill merupakan tahapan lanjut dari lower order thinking atau dalam bahasa yang lain, sebelum seseorang mampu berpikir pada 3 tahapan di atas, di mesti belajar melalui tiga tahapan di bawahnya. 


\section{Jurnal Pendidikan Jasmani Indonesia, 15 (1), 2019 - 36}

Ahmad Rithaudin, Indah Prasetyowati Tri Purnama Sari

\section{Tahapan kognitif anak usia SMA}

Anak usia SMA mempunyai rentang usia antara 15-18 tahun. Pada rentang ini, anak cenderung telah memiliki kemampuan kognitif yang lebih baik dibandingkan dengan anak pada usia di bawahnya. Seperti yang dikatakan oleh Johnson \& Johnson (2009, p.63) bahwa berdasar pendapat Piaget, anak usia 12-18 tahun termasuk dalam tahapan paling komplek perkembangan kognitifnya. Anak sudah dapat berpikir secara hipotetik dengan baik, berpikir logis dengan penggambaran, kemampuan verbal yang baik dalam berpikir logis.

Mengacu pada penjelasan sebelumnya/tabel 1. Dapat dilihat bahwa sebagian besar narasi kompetensi dasar dalam pembelajaran penjas terutama anak SMA kelas X di awali dengan menganalisis. Hal ini berarti kemampuan menganalisis inilah yang mendapat porsi terbesar untuk dikembangkan pada diri siswa terutama pada aspek kognitif. Berdasar hirarki yang disajikan oleh Bloom tersebut, kemmapuan untuk menganalisis juga termasuk kemampuan yang cukup tinggi levelnya, yaitu nomor tiga dari atas atau nomor empat ari dasar. $\mathrm{Hal}$ ini bisa diindikasikan bahwa, harapan yang dibangun dengan kurikulum tahun 2013 ini, siswa SMA mampu untuk bisa mengembangkan diri mereka terutama dalam hal kemampuan menganalisis. Meskipun tidak mengesampingkan hirarki di bawahnya.

\section{METODE}

Desain dalam penelitian ini adalah analisis dokumen, istilah lain dari analisis dokumen dalah content analysis. Analisis dokumen dapat dilakukan untuk menganalisis isi buku dengan menghitung istilah, konsep, diagram, tabel, gambar dan sebagainya untuk mengetahui klasifikasi dokumen yang dianalisis (Arikunto, 2002, p.88). Penelitian ini akan menganalisis sebuah dokumen yaitu Rencana Pelaksanaan Pembelajaran (RPP) pembelajaran pendidikan jasmani olahraga dan kesehatan (penjasorkes) di sekolah menengan atas se-DIY. Dokumen akan dianalisis sedemikian rupa untuk didapatkan hasil penelitian yaitu berkaitan dengan model aktivitas pembelajaran aspek kognitif dalam penjasorkes. Populasi dalam penelitian ini adalah sekolah menengah atas dan sekolah menengah kejuruan di lingkungan Dinas Pendidikan Daerah Istimewa Yogyakarta yang menjadi sekolah mitra UNY. Adapun jumlah sekolah yang dijadikan populasi adalah sejumlah 21 sekolah terdiri atas 17 SMA dan 4 SMK. Sampel penelitian ini adalah salah satu RPP dalam pembelajaran penjasorkes dengan ketentuan khusus yaitu RPP yang dianggap oleh guru paling baik. Sampai dengan proses pelaporan ini, peneliti mendapatkan 19 data/RPP dari 19 sekolah. Instrumen dalam penelitian ini menggunakan lembar dokumentasi yang sengaja disusun oleh peneliti untuk mengungkap permasalahan yang diteliti. Secara umum data yang dihasilkan dari penelitian ini adalah berupa dokumen, sehingga data berupa data sekunder. Data yang dikumpulkan berupa isi dari RPP yang didapatkan dari sekolah mitra. Teknik analisis data dalam penelitian ini adalah dengan menggunakan teknik analisis data deskriptif kuantitatif dan kualitatif. Analisis data kuantitatif dilakukan untuk untuk menggolongkan hasil penelitian berdasar kecenderungan terhadap sesuai, sebagai contoh data berupa model RPP berdasar kurikulum tahun 2006 atau 2013.

\section{HASIL DAN PEMBAHASAN}

\section{Hasil}

Hasil analisis terhadap dokumen RPP yang berhasil didapatkan dari sekolah yang dijadikan subjek penelitian. Hasil analisis terhadap RPP tersebut meliputi beberapa hal yang akan disajikan Tabel 1. Identifikasi kurikulum yang mendasari RPP sampel.

Kurikulum yang digunakan

Tabel 1. Model kurikulum dalam RPP sampel

\begin{tabular}{clcc}
\hline No. & \multicolumn{1}{c}{ Jenis RPP } & Jumlah & Persentase (\%) \\
\hline 1. & Kurikulum tahun 2006 & 8 & 42 \\
2. & Kurikulum tahun 2013 & 11 & 58 \\
& Jumlah & 19 & 100 \\
\hline
\end{tabular}


Jurnal Pendidikan Jasmani Indonesia, 15 (1), 2019 - 37

Ahmad Rithaudin, Indah Prasetyowati Tri Purnama Sari

Kelas yang dianalisis

Tabel 2. Tingkatan kelas dalam RPP sampel

\begin{tabular}{|c|c|c|c|}
\hline No. & Tingkatan Kelas & Jumlah & Persentase (\%) \\
\hline 1. & Kelas X & 9 & 47 \\
\hline 2. & Kelas XI & 7 & 37 \\
\hline 3. & Kelas XII & $\begin{array}{c}3 \\
19\end{array}$ & 16 \\
\hline
\end{tabular}

Materi pembelajaran yang dianalisis

Tabel 3. Jenis materi dalam RPP sampel

\begin{tabular}{clcc}
\hline No. & \multicolumn{1}{c}{ Materi Pembelajaran } & Jumlah & Persentase $(\%)$ \\
\hline 1. & Permainan bolabesar & 15 & 79 \\
2. & Atletik & 1 & 5 \\
3. & Kebugaran jasmani & 2 & 11 \\
4. & Uji diri/senam & 1 & 5 \\
& Jumlah & 19 & 100 \\
\hline
\end{tabular}

Analisis indikator dilakukan untuk menganalisis sejauh mana seorang guru menjabarkan kompetensi dasar sehingga rencana pembelajaran menjadi lebih terfokus. Satu kompetensi dasar dapat dijabarkan ke dalam beberapa indikator, meskipun dalam beberapa kesempatan disampaikan bahwa satu kompetensi dasar paling tidak dijabarkan menjadi dua indikator. Tabel 4 disajikan hasil analisis isi terhadap indikator hasil penjabaran dari guru yang merancang pembelajaran yang akan disajikan.

Tabel 4. Kata kunci indikator aspek kognitif

\begin{tabular}{l} 
Kata Kunci Indikator Aspek Kognitif \\
\hline - Menjelaskan konsep gerak fundamental teknik dasar melempar \\
- Mengidentifikasi rangkaian gerak melempar \\
- Menjelaskan kesalahan-kesalahan dalam melakukan sikap akhir passing melempar \\
- Analisis gerakan melempar dalam permainan \\
- Menganalisis latihan kebugaran jasmani \\
- Merancang latihan kebugaran jasmani \\
- Mengevaluasi latihan kebugaran jasmani \\
- Menganalisis variasi dan kombinasi teknik dasar melempar, menangkap, menggiring dan \\
- Menembak bola untuk menghasilkan koordinasi yang baik. \\
- - Merketukan teknik dasar passing bawah dan passing atas bolavoli secara berpasangan dan \\
- - Merpasangananian dan komban berkinasis keterampilan teknik dasar passing bawah dan passing atas bolavoli secara \\
- Menjelaskan tahapan teknik dasar permainan bolabasket \\
- Menentukan variasi dan kombinasi teknik dasar permainan bolabasket \\
- Menganalisis kelebihan dan kelemahan variasi dan kombinasi teknik dasar permainan bolabasket \\
- Menganalisis dan mempraktikkan teknik dasar permainan bolabasket \\
- Menjelaskan tahapan teknik dasar permainan sepakbola \\
- Menemukan variasi dan kombinasi teknik dasar permainan sepakbola \\
- Menganalisis kelebihan dan kelemahan variasi dan kombinasi teknik dasar permainan sepakbola \\
- Menganalisis variasi dan kombinasi keterampilan gerak salah satu permainan bolabesar untuk \\
- Menghasilkan koordinasi gerak yang baik \\
- Menjelaskan macam-macam teknik dasar permainan bolabesar \\
- Menyebutkan komsep latihan kebugaran jasmani \\
- Mendeskripsikan konsen kebugaran jasmani \\
- Mendeskripsikan bentuk latihan kekuatan otot lengan, otot perut, otot punggung. \\
- Menganalisis pola penyerangan dan pertahanan. \\
- Merancang taktik dan strategi \\
- Menjelaskan pola penyerangan dan pertahanan
\end{tabular}


Jurnal Pendidikan Jasmani Indonesia, 15 (1), 2019 - 38

Ahmad Rithaudin, Indah Prasetyowati Tri Purnama Sari

- Mengevaluasi pola penyerangan

Tabel 5. Analisis isi materi dalam RPP

Kata Kunci materi Aspek Kognitif

- Apersepsi: mengaitkan materi terdahulu dengan sekarang.

- Menjelaskan tujuan pembelajaran

- Siswa mendiskusikan lembar kerja dari guru

- Siswa klarifikasi dan konfirmasi kepada guru terhadap materi diskusi

- Melakukan pengamatan terhadap gerakan teman dan koreksi

- Apersepsi: mengaitkan materi terdahulu dengan sekarang.

- Menjelaskan tujuan pembelajaran

- Menjelaskan bentuk tes dari materi pembelajaran

- Mendiskusikan gerakan push-up perbedaan antara putera dan puteri

- Mendiskusikan gerakan sit-up perbedaan antara putera dan puteri

- Mendiskusikan variasi gerakan push dan sit-up

- Mempresentasikan hasil diskusi

- Menjelaskan tujuan pembelajaran

- Mendiskusikan gerak dasar bolabasket dan menemukan kesalahannya.

- Mendiskusikan cara memperbaiki kesahalannya.

- Membandingkan gerak antara pertandingan yang diamati dengan gerak dasar teman sekelas.

- Menjelaskan tujuan dan materi pembelajaran

- Mendiskusikan gerak dasar bolavoli dan menarik kesimpulannya.

- Siswa mengajukan pertanyaan tentang teknik dasar bolabasket

- Mencari info tentang gerak dasar, mendiskusikan kesalahan yang sering muncul di kelas dan menganalisis untuk memperbaiki.

- Menjelaskan KD, Tujuan pembelajaran

- Siswa mengemukakan pengalaman setelah melihat atau melakukan permainan bolabasket

- Mengaitkan materi hasil amatan dengan ,materi pembelajaran

- Menyimak peragaan gerak dari rekan yang lain, mengamati, mengajukan pertanyaan.

- Mendiskusikan gerak dasar permainan secara berkelompok dan saling member tanggapan

- Menjelaskan tujuan dan materi pembelajaran

- Mengamati dari berbagai sumber tentang materi pembelajaran

- Mengaitkan materi sebelumnya dengan hari ini

- Menjelaskan tujuan dan materi pembelajaran

- Mengamati dari berbagai sumber tentang materi pembelajaran kemudian mengemukakan di depan kelas

- Menyimak peragaan, menganalisis gerakan dan menanya.

- Siswa dalam kelompok mendiskusikan materi, gerakan yang benar disertai alasan dan argumen.

- Saling memberi tanggapan dengan kelompok lain setelah bermain.

- Mengaitkan materi sebelumnya dengan hari ini

- Menjelaskan tujuan dan materi pembelajaran

- Siswa dalam kelompok mendiskusikan materi, gerakan yang benar disertai alasan dan argumen.

- Menyimpulkan materi gerak dasar yang dipelajari

- Melaporkan hasil pengamatan melalui video ataupun pengamatan langsung terhadap materi.

- Siswa mengamati gerakan kekuatan

- Mendiskusikan kesalahan gerakan dan cara memperbaikinya.

- Memilih bentuk latihan yang cocok

- Melihat dan mendengar penjelasan dari guru dari slide

- Mendiskusikan strategi dan taktik, kelebihan, kekurangan dan cara memeperbaiki kesalahan.

- Penjelasan cara melalukan gerak dasar.

- Menyimpulkan tentang hal-hal yang belum diketahui.

- Penjelasan tujuan pembelajaran

- Penjelasan cara melakukan gerak dasar permainan

- Diskusi dan Tanya jawab terhadap proses yang dilakukan

- Penjelasan tujuan pembelajaran

- Penjelasan cara melakukan gerak dasar lompat tinggi

- Menjelaskan kembali terhadap hal-hal yang belum diketahui dan menyimpulkan materi. 
- Diskusi dan Tanya jawab terhadap proses yang dilakukan

- Penjelasan tujuan pembelajaran

- Penjelasan cara melakukan gerak dasar senam

- Mendiskusikan materi yang telah dipelajari

- Penjelasan tujuan pembelajaran

- Penjelasan cara melakukan gerak dasar permainan bolabasket

- Mendiskusikan materi yang telah dipelajari

- Menjelaskan kembali terhadap hal-hal yang belum diketahui dan menyimpulkan materi.

- Menjelaskan cara melakukan latihan koordinasi teknik dasar sepakbola

Berdasar Tabel 4 dapat diketahui bahwa semua guru telah merancang pembelajaran pada aspek kognitif dalam bentuk indikator dengan kata kunci yang mengacu pada level kognitif yang lebih rendah dan lebih tinggi. Hal ini tercermin dari beberapa kata yang dicetak miring dan tidak dicetak mirim dalam tabel di atas. Adapun tingkatan/hirarki aspek kognitif yang tercermin dalam indikator tersebut meliputi tingkatan dasar sampai dengan tingkatan teratas. Contoh kata kunci indikator pada hirarki kognitif tingkat dasar adalah "menyebutkan" dan "mengidentifikasi" sedangkan hirarki kognitif tingkat teratas tergambar dalam kata "merancang" yang hal ini relevan dengan istilah "creating". Berdasar pada tabel tersebut juga telah banyak muncul kata kunci indikator yang mengarah pada tingkatan berpikir yang lebih tinggi (Higher Order Thinking Skill) diantaranya yaitu "menganalisis" dan "menentukan".

Ruang lingkup materi aspek kognitif dari RPP hasil analisis.

Setelah analisis terhadap indikator pembelajaran, maka tahapan analisis selanjutnya adalah menganalisis konten materi pembelajaran. Analisis ini diharapkan mampu menganalisis isi materi pembelajaran yang berkaitan dengan aspek kognitif (Tabel 5).

Berdasar Tabel 5 diketahui bahwa telah dirancang pula dalam aktivitas pembelajaran aspek kognitif dalam inti kegiatan pembelajaran yang tercantum dalam RPP. Aktivitas-aktivitas tersebut merupakan kombinasi dari aktivitas yang dilakukan oleh guru ataupun oleh siswa. Oleh guru, aktivitas tersebut umumnya berupa penjelasan terhadap siswa. Sedangkan oleh siswa, aktivitas yang berkaitan dengan pembelajaran aspek kognitif dirancang pada aktivitas untuk menjelaskan sampai dengan mendiskusikan ataupun menentukan pilihan/memutuskan sesuatu hal.

Apabila dianalisis berdasar pada hasil dari Tabel 4 dan Tabel 5. Ditemukan beberapa aktivitas yang kurang relevan. beberapa diantaranya yaitu pada tahapan inti pembelajaran, belum tertuang aktivitas riil dari penjabaran indikator yang telah mencapai level/hirarki yang lebih tinggi (higher order thinking skill). Hal ini dirasa kurang relevan karena rancangan indikator yang telah dikatakan baik menjadi berkurang tingkatannya karena justru aktivitas yang muncul yaitu pada level/hirarki yang tidak sama dengan indikator yang ada. hal ini bisa disebabkan oleh kurang cermatnya penyusun RPP dalam mengembangkan materi inti. Namun, dalam implementasinya hal ini belum bisa dikatakan bahwa materi juga tidak dilaksanakan karena batasan penelitian ini hanya pada lingkup RPP. Salah satu rekomendasi yang peneliti berikan adalah perlunya pengamatan secara langsung dilapangan terhadap rancangan pembelajaran aspek kognitif yang telah tertuang dalam RPP sehingga pembelajaran akan berjalan dengan baik dan seluruh kompetensi dalam diri anak dapat berkembang.

\section{SIMPULAN}

Berdasar hasil penelitian dan pembahasan yang telah dilakukan dapat disimpulkan bahwa secara umum terdapat materi pembelajaran pada aspek kognitif dalam RPP pembelajaran penjasorkes SMA Mitra UNY di DIY. Tingkatan pembelajaran aspek kognitif yang muncul dalam indikator ketercapaian pembelajaran telah menunjukkan bahwa pembelajaran telah mencapai level kognitif yang tinggi (higher order thinking skill). Meskipun, dalam penjabaran materi pembelajaran hal ini justru belum tersampaikan secara tertulis. 
Jurnal Pendidikan Jasmani Indonesia, 15 (1), 2019 - 40

Ahmad Rithaudin, Indah Prasetyowati Tri Purnama Sari

\section{DAFTAR PUSTAKA}

Abdullah, A., \& Manadji, A. (1994). Dasar-dasar pendidikan jasmani. Jakarta: Departemen Pendidikan dan Kebudayaan.

Arikunto, S. (2002). Prosedur penelitian (suatu pendekatan praktek). Jakarta: Rineka Cipta.

Bucher, C. A., \& Wuest, D. A. (1983). Foundation of physical education and sport. London, The CV Mosby Company.

Harefa, A. (2000). Menjadi manusia pembelajar: Pemberdayaan diri, transformasi organisasi dan masyarakat lewat proses pembelajaran: menuju Indonesia 2045. Penerbit Harian Kompas.

Johnson, D. W., \& Johnson, R. T. (2009). An educational psychology success story: Social interdependence theory and cooperative learning. Educational Researcher, 38(5), 365379.

Mendikbud. (2013). Lampiran Permendikbud No.69 Tahun 2013. Jakarta: Kemendikbud.

Mendiknas. (2003). Undang-undang sistem pendidikan Nasional no.20 tahun 2003. Jakarta: Kemendiknas.

Mendiknas. (2006). Kurikulum mata pelajaran penjasorkes. Jakarta: Kemendikbud.

Siyamta. (2013). Ranah kognitif dalam pembelajaran (paper). Malang: Program PPS Universitas Negeri Malang

Utari, R. (2013). Taksonomi Bloom apa dan bagaimana menggunakannya. Jakarta: Pusdiklat KNPK. 